\title{
Two P domain potassium channels in GtoPdb v.2021.2
}

\author{
Austin M. Baggetta ${ }^{1}$, Douglas A. Bayliss ${ }^{2}$, Gábor Czirják ${ }^{3}$, Péter Enyedi ${ }^{3}$, Steve A.N. Goldstein ${ }^{4}$,
} Florian Lesage ${ }^{5}$, Daniel L. Minor, Jr. ${ }^{6}$, Leigh D. Plant ${ }^{1}$, Francisco Sepúlveda ${ }^{7}$ and Brenda T. Winn ${ }^{1}$

1. Northeastern University, USA

2. University of Virginia Health System, USA

3. Semmelweis University, Hungary

4. Brandeis UniversityLoyola University Chicago, USA

5. Université de Nice, France

6. University of California San Francisco, USA

7. Centro de Estudios Científicos, Chile

\begin{abstract}
The 4TM family of $\mathrm{K}$ channels mediate many of the background potassium currents observed in native cells. They are open across the physiological voltage-range and are regulated by a wide array of neurotransmitters and biochemical mediators. The pore-forming $\alpha$-subunit contains two pore loop (P) domains and two subunits assemble to form one ion conduction pathway lined by four P domains. It is important to note that single channels do not have two pores but that each subunit has two $\mathrm{P}$ domains in its primary sequence; hence the name two $\mathrm{P}$ domain, or $\mathrm{K}_{2 \mathrm{P}}$ channels (and not two-pore channels). Some of the $\mathrm{K}_{2 \mathrm{P}}$ subunits can form heterodimers across subfamilies (e.g. $\mathrm{K}_{2 \mathrm{P}} 3.1$ with $\mathrm{K}_{2 \mathrm{P}}$ 9.1). The nomenclature of $4 \mathrm{TM} \mathrm{K}$ channels in the literature is still a mixture of IUPHAR and common names. The suggested division into subfamilies, described in the More detailed introduction, is based on similarities in both structural and functional properties within subfamilies and this explains the "common abbreviation" nomenclature in the tables below.
\end{abstract}

\section{Contents}

This is a citation summary for Two P domain potassium channels in the Guide to Pharmacology database (GtoPdb). It exists purely as an adjunct to the database to facilitate the recognition of citations to and from the database by citation analyzers. Readers will almost certainly want to visit the relevant sections of the database which are given here under database links.

GtoPdb is an expert-driven guide to pharmacological targets and the substances that act on them. GtoPdb is a reference work which is most usefully represented as an on-line database. As in any publication this work should be appropriately cited, and the papers it cites should also be recognized. This document provides a citation for the relevant parts of the database, and also provides a reference list for the research cited by those parts. For further details see [12].

Please note that the database version for the citations given in GtoPdb are to the most recent preceding version in which the family or its subfamilies and targets were substantially changed. The links below are to the current version. If you need to consult the cited version, rather than the most recent version, please contact the GtoPdb curators.

\section{Database links}

Two P domain potassium channels

https://www.guidetopharmacology.org/GRAC/FamilyDisplayForward?familyId=79

Introduction to Two P domain potassium channels

https://www.guidetopharmacology.org/GRAC/FamilyIntroductionForward?familyId=79

Channels and Subunits

TWIK1 $\left(\mathrm{K}_{2 \mathrm{P}} 1.1\right)$

https://www.guidetopharmacology.org/GRAC/ObjectDisplayForward?objectId=513

$\operatorname{TREK} 1\left(\mathrm{~K}_{2 \mathrm{P}} 2.1\right)$ 
https://www.guidetopharmacology.org/GRAC/ObjectDisplayForward?objectId=514 TASK1 $\left(\mathrm{K}_{2 \mathrm{P}} 3.1\right)$

https://www.guidetopharmacology.org/GRAC/ObjectDisplayForward?objectId=515 TRAAK1 $\left(\mathrm{K}_{2 \mathrm{P}} 4.1\right)$

https://www.guidetopharmacology.org/GRAC/ObjectDisplayForward?objectId=516 TASK2 $\left(\mathrm{K}_{2} \mathrm{P}^{5.1}\right)$

https://www.guidetopharmacology.org/GRAC/ObjectDisplayForward?objectId=517 TWIK2 $\left(\mathrm{K}_{2 \mathrm{P}} 6.1\right)$

https://www.guidetopharmacology.org/GRAC/ObjectDisplayForward?objectId=518 $\mathrm{K}_{2 \mathrm{P}} 7.1$

https://www.guidetopharmacology.org/GRAC/ObjectDisplayForward?objectId=519 TASK3(K $\left.2 \mathrm{P}^{9.1}\right)$

https://www.guidetopharmacology.org/GRAC/ObjectDisplayForward?objectId=520 TREK2 $\left(\mathrm{K}_{2 \mathrm{P}} 10.1\right)$

https://www.guidetopharmacology.org/GRAC/ObjectDisplayForward?objectId=521 THIK2(K $2 \mathrm{P} 12.1)$

https://www.guidetopharmacology.org/GRAC/ObjectDisplayForward?objectId=522 THIK1 $\left(\mathrm{K}_{2 \mathrm{P}} 13.1\right)$

https://www.guidetopharmacology.org/GRAC/ObjectDisplayForward?objectId=523 TASK5 $\left(K_{2 \mathrm{P}} 15.1\right)$

https://www.guidetopharmacology.org/GRAC/ObjectDisplayForward?objectId=524 TALK1 $\left(\mathrm{K}_{2 \mathrm{P}} 16.1\right)$

https://www.guidetopharmacology.org/GRAC/ObjectDisplayForward?objectId=525

TALK2 $\left(\mathrm{K}_{2 \mathrm{P}} 17.1\right)$

https://www.guidetopharmacology.org/GRAC/ObjectDisplayForward?objectId=526 $\operatorname{TRESK}\left(\mathrm{K}_{2 \mathrm{P}} 18.1\right)$

https://www.guidetopharmacology.org/GRAC/ObjectDisplayForward?objectId=527

\section{References}

1. Andres-Enguix I, Shang L, Stansfeld PJ, Morahan JM, Sansom MS, Lafrenière RG, Roy B, Griffiths LR, Rouleau GA and Ebers GC et al.. (2012) Functional analysis of missense variants in the TRESK (KCNK18) K channel. Sci Rep 2: 237 [PMID:22355750]

2. Añazco C, Peña-Münzenmayer G, Araya C, Cid LP, Sepúlveda FV and Niemeyer MI. (2013) G protein modulation of K2P potassium channel TASK-2 : a role of basic residues in the $\mathrm{C}$ terminus domain. Pflugers Arch 465: 1715-26 [PMID:23812165]

3. Bang H, Kim Y and Kim D. (2000) TREK-2, a new member of the mechanosensitive tandem-pore K+ channel family. J Biol Chem 275: 17412-9 [PMID:10747911]

4. Barel O, Shalev SA, Ofir R, Cohen A, Zlotogora J, Shorer Z, Mazor G, Finer G, Khateeb S and Zilberberg $\mathrm{N}$ et al.. (2008) Maternally inherited Birk Barel mental retardation dysmorphism syndrome caused by a mutation in the genomically imprinted potassium channel KCNK9. Am J Hum Genet 83: 193-9 [PMID:18678320]

5. Barriere H, Belfodil R, Rubera I, Tauc M, Lesage F, Poujeol C, Guy N, Barhanin J and Poujeol P. (2003) Role of TASK2 potassium channels regarding volume regulation in primary cultures of mouse proximal tubules. J Gen Physiol 122: 177-90 [PMID:12860925]

6. Berg AP, Talley EM, Manger JP and Bayliss DA. (2004) Motoneurons express heteromeric TWIKrelated acid-sensitive K+ (TASK) channels containing TASK-1 (KCNK3) and TASK-3 (KCNK9) subunits. J Neurosci 24: 6693-702 [PMID:15282272]

7. Blin S, Ben Soussia I, Kim EJ, Brau F, Kang D, Lesage F and Bichet D. (2016) Mixing and matching TREK/TRAAK subunits generate heterodimeric K2P channels with unique properties. Proc Natl Acad Sci USA 113: 4200-5 [PMID:27035965]

8. Blin S, Chatelain FC, Feliciangeli S, Kang D, Lesage F and Bichet D. (2014) Tandem pore domain halothane-inhibited $\mathrm{K}+$ channel subunits THIK1 and THIK2 assemble and form active channels. J Biol Chem 289: 28202-12 [PMID:25148687]

9. Bockenhauer D, Nimmakayalu MA, Ward DC, Goldstein SA and Gallagher PG. (2000) Genomic organization and chromosomal localization of the murine $2 \mathrm{P}$ domain potassium channel gene Kcnk8: conservation of gene structure in 2 P domain potassium channels. Gene 261: 365-72 [PMID:11167025]

10. Bockenhauer D, Zilberberg N and Goldstein SA. (2001) KCNK2: reversible conversion of a hippocampal potassium leak into a voltage-dependent channel. Nat Neurosci 4: 486-91 [PMID:11319556]

11. Buckler KJ, Williams BA and Honore E. (2000) An oxygen-, acid- and anaesthetic-sensitive TASKlike background potassium channel in rat arterial chemoreceptor cells. J Physiol (Lond.) 525 Pt 
1: 135-42 [PMID:10811732]

12. Buneman P, Christie G, Davies JA, Dimitrellou R, Harding SD, Pawson AJ, Sharman JL and Wu Y. (2020) Why data citation isn't working, and what to do about it Database 2020 [PMID:32367113]

13. Cazals Y, Bévengut M, Zanella S, Brocard F, Barhanin J and Gestreau C. (2015) KCNK5 channels mostly expressed in cochlear outer sulcus cells are indispensable for hearing. Nat Commun 6: 8780 [PMID:26549439]

14. Chapman CG, Meadows HJ, Godden RJ, Campbell DA, Duckworth M, Kelsell RE, Murdock PR, Randall AD, Rennie GI and Gloger IS. (2000) Cloning, localisation and functional expression of a novel human, cerebellum specific, two pore domain potassium channel. Brain Res Mol Brain Res 82: 74-83 [PMID:11042359]

15. Chatelain FC, Bichet D, Feliciangeli S, Larroque MM, Braud VM, Douguet D and Lesage F. (2013) Silencing of the tandem pore domain halothane-inhibited K+ channel 2 (THIK2) relies on combined intracellular retention and low intrinsic activity at the plasma membrane. $\mathrm{J} \mathrm{Biol} \mathrm{Chem}$ 288: 35081-92 [PMID:24163367]

16. Comoglio Y, Levitz J, Kienzler MA, Lesage F, Isacoff EY and Sandoz G. (2014) Phospholipase D2 specifically regulates TREK potassium channels via direct interaction and local production of phosphatidic acid. Proc Natl Acad Sci USA 111: 13547-52 [PMID:25197053]

17. Czirják G and Enyedi P. (2002) Formation of functional heterodimers between the TASK-1 and TASK-3 two-pore domain potassium channel subunits. J Biol Chem 277: 5426-32 [PMID:11733509]

18. Czirják G and Enyedi P. (2014) The LQLP calcineurin docking site is a major determinant of the calcium-dependent activation of human TRESK background K+ channel. J Biol Chem 289: 29506-18 [PMID:25202008]

19. Czirják G and Enyedi P. (2006) Targeting of calcineurin to an NFAT-like docking site is required for the calcium-dependent activation of the background K+ channel, TRESK. J Biol Chem 281: 14677-82 [PMID:16569637]

20. Czirják G, Fischer T, Spät A, Lesage F and Enyedi P. (2000) TASK (TWIK-related acid-sensitive $\mathrm{K}+$ channel) is expressed in glomerulosa cells of rat adrenal cortex and inhibited by angiotensin II. Mol Endocrinol 14: 863-74 [PMID:10847588]

21. Czirják G, Tóth ZE and Enyedi P. (2004) The two-pore domain K+ channel, TRESK, is activated by the cytoplasmic calcium signal through calcineurin. J Biol Chem 279: 18550-8 [PMID:14981085]

22. Czirják G, Vuity D and Enyedi P. (2008) Phosphorylation-dependent binding of 14-3-3 proteins controls TRESK regulation. J Biol Chem 283: 15672-80 [PMID:18397886]

23. Decher N, Wemhöner K, Rinné S, Netter MF, Zuzarte M, Aller MI, Kaufmann SG, Li XT, Meuth SG and Daut J et al.. (2011) Knock-out of the potassium channel TASK-1 leads to a prolonged QT interval and a disturbed QRS complex. Cell Physiol Biochem 28: 77-86 [PMID:21865850]

24. Decressac S, Franco M, Bendahhou S, Warth R, Knauer S, Barhanin J, Lazdunski M and Lesage F. (2004) ARF6-dependent interaction of the TWIK1 K+ channel with EFA6, a GDP/GTP exchange factor for ARF6. EMBO Rep 5: 1171-5 [PMID:15540117]

25. Dong YY, Pike AC, Mackenzie A, McClenaghan C, Aryal P, Dong L, Quigley A, Grieben M, Goubin S and Mukhopadhyay S et al.. (2015) K2P channel gating mechanisms revealed by structures of TREK-2 and a complex with Prozac. Science 347: 1256-9 [PMID:25766236]

26. Duprat F, Girard C, Jarretou G and Lazdunski M. (2005) Pancreatic two P domain K+ channels TALK-1 and TALK-2 are activated by nitric oxide and reactive oxygen species. J Physiol (Lond.) 562: 235-44 [PMID:15513946]

27. Duprat F, Lesage F, Fink M, Reyes R, Heurteaux C and Lazdunski M. (1997) TASK, a human background $\mathrm{K}+$ channel to sense external $\mathrm{pH}$ variations near physiological $\mathrm{pH}$. EMBO J 16: 5464-71 [PMID:9312005]

28. Duprat F, Lesage F, Patel AJ, Fink M, Romey G and Lazdunski M. (2000) The neuroprotective agent riluzole activates the two P domain $\mathrm{K}(+)$ channels TREK-1 and TRAAK. Mol Pharmacol 57: 906-12 [PMID:10779373]

29. Enyedi P, Veres I, Braun G and Czirják G. (2014) Tubulin binds to the cytoplasmic loop of TRESK background $\mathrm{K}^{+}$channel in vitro. PLoS ONE 9: e97854 [PMID:24830385]

30. Fink M, Duprat F, Lesage F, Reyes R, Romey G, Heurteaux C and Lazdunski M. (1996) Cloning, functional expression and brain localization of a novel unconventional outward rectifier $\mathrm{K}+$ channel. EMBO J 15: 6854-62 [PMID:9003761]

31. Fink M, Lesage F, Duprat F, Heurteaux C, Reyes R, Fosset M and Lazdunski M. (1998) A neuronal two $\mathrm{P}$ domain $\mathrm{K}+$ channel stimulated by arachidonic acid and polyunsaturated fatty acids. EMBO J 17: 3297-308 [PMID:9628867]

32. Friedrich C, Rinné S, Zumhagen S, Kiper AK, Silbernagel N, Netter MF, Stallmeyer B, SchulzeBahr E and Decher N. (2014) Gain-of-function mutation in TASK-4 channels and severe cardiac conduction disorder. EMBO Mol Med 6: 937-51 [PMID:24972929]

33. Gabriel A, Abdallah M, Yost CS, Winegar BD and Kindler CH. (2002) Localization of the tandem 
pore domain K+ channel KCNK5 (TASK-2) in the rat central nervous system. Brain Res Mol Brain Res 98: 153-63 [PMID:11834308]

34. Girard C, Duprat F, Terrenoire C, Tinel N, Fosset M, Romey G, Lazdunski M and Lesage F. (2001) Genomic and functional characteristics of novel human pancreatic 2P domain $\mathrm{K}(+)$ channels. Biochem Biophys Res Commun 282: 249-56 [PMID:11263999]

35. Goldstein SA, Wang KW, Ilan N and Pausch MH. (1998) Sequence and function of the two $P$ domain potassium channels: implications of an emerging superfamily. J Mol Med 76: 13-20 [PMID:9462864]

36. Gomes AQ, Correia DV, Grosso AR, Lança T, Ferreira C, Lacerda JF, Barata JT, Silva MG and Silva-Santos B. (2010) Identification of a panel of ten cell surface protein antigens associated with immunotargeting of leukemias and lymphomas by peripheral blood gammadelta T cells. Haematologica 95: 1397-404 [PMID:20220060]

37. Gray AT, Kindler CH, Sampson ER and Yost CS. (1999) Assignment of KCNK6 encoding the human weak inward rectifier potassium channel TWIK-2 to chromosome band 19q13.1 by radiation hybrid mapping. Cytogenet Cell Genet 84: 190-1 [PMID:10393428]

38. Gray AT, Zhao BB, Kindler CH, Winegar BD, Mazurek MJ, Xu J, Chavez RA, Forsayeth JR and Yost CS. (2000) Volatile anesthetics activate the human tandem pore domain baseline $\mathrm{K}+$ channel KCNK5. Anesthesiology 92: 1722-30 [PMID:10839924]

39. Gu W, Schlichthörl G, Hirsch JR, Engels H, Karschin C, Karschin A, Derst C, Steinlein OK and Daut J. (2002) Expression pattern and functional characteristics of two novel splice variants of the two-pore-domain potassium channel TREK-2. J Physiol (Lond.) 539: 657-68 [PMID:11897838]

40. Han J, Kang D and Kim D. (2003) Functional properties of four splice variants of a human pancreatic tandem-pore K+ channel, TALK-1. Am J Physiol, Cell Physiol 285: C529-38 [PMID:12724142]

41. Han J, Truell J, Gnatenco C and Kim D. (2002) Characterization of four types of background potassium channels in rat cerebellar granule neurons. J Physiol (Lond.) 542: 431-44 [PMID:12122143]

42. Heitzmann D, Derand R, Jungbauer S, Bandulik S, Sterner C, Schweda F, El Wakil A, Lalli E, Guy N and Mengual R et al.. (2008) Invalidation of TASK1 potassium channels disrupts adrenal gland zonation and mineralocorticoid homeostasis. EMBO J 27: 179-87 [PMID:18034154]

43. Heurteaux C, Guy N, Laigle C, Blondeau N, Duprat F, Mazzuca M, Lang-Lazdunski L, Widmann C, Zanzouri M and Romey G et al.. (2004) TREK-1, a K+ channel involved in neuroprotection and general anesthesia. EMBO J 23: 2684-95 [PMID:15175651]

44. Hsu K, Seharaseyon J, Dong P, Bour S and Marbán E. (2004) Mutual functional destruction of HIV-1 Vpu and host TASK-1 channel. Mol Cell 14: 259-67 [PMID:15099524]

45. Hwang EM, Kim E, Yarishkin O, Woo DH, Han KS, Park N, Bae Y, Woo J, Kim D and Park M et al.. (2014) A disulphide-linked heterodimer of TWIK-1 and TREK-1 mediates passive conductance in astrocytes. Nat Commun 5: 3227 [PMID:24496152]

46. Kang D, Choe C and Kim D. (2005) Thermosensitivity of the two-pore domain K+ channels TREK-2 and TRAAK. J Physiol (Lond.) 564: 103-16 [PMID:15677687]

47. Kang D, Choe C and Kim D. (2004) Functional expression of TREK-2 in insulin-secreting MIN6 cells. Biochem Biophys Res Commun 323: 323-31 [PMID:15351740]

48. Kang D, Han J, Talley EM, Bayliss DA and Kim D. (2004) Functional expression of TASK-1/TASK3 heteromers in cerebellar granule cells. J Physiol (Lond.) 554: 64-77 [PMID:14678492]

49. Kang D and Kim D. (2004) Single-channel properties and pH sensitivity of two-pore domain K+ channels of the TALK family. Biochem Biophys Res Commun 315: 836-44 [PMID:14985088]

50. Kennard LE, Chumbley JR, Ranatunga KM, Armstrong SJ, Veale EL and Mathie A. (2005) Inhibition of the human two-pore domain potassium channel, TREK-1, by fluoxetine and its metabolite norfluoxetine. Br J Pharmacol 144: 821-9 [PMID:15685212]

51. Kim D, Cavanaugh EJ, Kim I and Carroll JL. (2009) Heteromeric TASK-1/TASK-3 is the major oxygen-sensitive background $\mathrm{K}+$ channel in rat carotid body glomus cells. J Physiol (Lond.) 587: 2963-75 [PMID:19403596]

52. Kim D, Fujita A, Horio Y and Kurachi Y. (1998) Cloning and functional expression of a novel cardiac two-pore background K+ channel (cTBAK-1). Circ Res 82: 513-8 [PMID:9506712]

53. Kim D and Gnatenco C. (2001) TASK-5, a new member of the tandem-pore K(+) channel family. Biochem Biophys Res Commun 284: 923-30 [PMID:11409881]

54. Kim D, Sladek CD, Aguado-Velasco C and Mathiasen JR. (1995) Arachidonic acid activation of a new family of $\mathrm{K}+$ channels in cultured rat neuronal cells. J Physiol (Lond.) 484 ( Pt 3): $643-60$ [PMID:7623282]

55. Kim E, Hwang EM, Yarishkin O, Yoo JC, Kim D, Park N, Cho M, Lee YS, Sun CH and Yi GS et al.. (2010) Enhancement of TREK1 channel surface expression by protein-protein interaction with beta-COP. Biochem Biophys Res Commun 395: 244-50 [PMID:20362547]

56. Kim SJ, Sohn I, Do IG, Jung SH, Ko YH, Yoo HY, Paik S and Kim WS. (2014) Gene expression profiles for the prediction of progression-free survival in diffuse large B cell lymphoma: results 
of a DASL assay. Ann Hematol 93: 437-47 [PMID:23975159]

57. Kim Y, Bang H and Kim D. (1999) TBAK-1 and TASK-1, two-pore K(+) channel subunits: kinetic properties and expression in rat heart. Am J Physiol 277: H1669-78 [PMID:10564119]

58. Kim Y, Bang H and Kim D. (2000) TASK-3, a new member of the tandem pore $\mathrm{K}(+)$ channel family. J Biol Chem 275: 9340-7 [PMID:10734076]

59. Kindler $\mathrm{CH}$, Yost CS and Gray AT. (1999) Local anesthetic inhibition of baseline potassium channels with two pore domains in tandem. Anesthesiology 90: 1092-102 [PMID:10201682]

60. Lafrenière RG, Cader MZ, Poulin JF, Andres-Enguix I, Simoneau M, Gupta N, Boisvert K, Lafrenière F, McLaughlan S and Dubé MP et al.. (2010) A dominant-negative mutation in the TRESK potassium channel is linked to familial migraine with aura. Nat Med 16: 1157-60 [PMID:20871611]

61. Lauritzen I, Zanzouri M, Honoré E, Duprat F, Ehrengruber MU, Lazdunski M and Patel AJ. (2003) K+-dependent cerebellar granule neuron apoptosis. Role of task leak K+ channels. J Biol Chem 278: 32068-76 [PMID:12783883]

62. Lazarenko RM, Willcox SC, Shu S, Berg AP, Jevtovic-Todorovic V, Talley EM, Chen X and Bayliss DA. (2010) Motoneuronal TASK channels contribute to immobilizing effects of inhalational general anesthetics. J Neurosci 30: 7691-704 [PMID:20519544]

63. Leonoudakis D, Gray AT, Winegar BD, Kindler CH, Harada M, Taylor DM, Chavez RA, Forsayeth JR and Yost CS. (1998) An open rectifier potassium channel with two pore domains in tandem cloned from rat cerebellum. J Neurosci 18: 868-77 [PMID:9437008]

64. Lesage F, Guillemare E, Fink M, Duprat F, Lazdunski M, Romey G and Barhanin J. (1996) TWIK1, a ubiquitous human weakly inward rectifying $\mathrm{K}+$ channel with a novel structure. EMBO J 15: 1004-11 [PMID:8605869]

65. Lesage F, Lauritzen I, Duprat F, Reyes R, Fink M, Heurteaux C and Lazdunski M. (1997) The structure, function and distribution of the mouse TWIK-1 K+ channel. FEBS Lett 402: 28-32 [PMID:9013852]

66. Lesage F, Maingret F and Lazdunski M. (2000) Cloning and expression of human TRAAK, a polyunsaturated fatty acids-activated and mechano-sensitive $\mathrm{K}(+)$ channel. FEBS Lett 471: 13740 [PMID:10767409]

67. Lesage F, Mattéi M, Fink M, Barhanin J and Lazdunski M. (1996) Assignment of the human weak inward rectifier K+ channel TWIK-1 gene to chromosome 1q42-q43. Genomics 34: 153-5 [PMID:8661042]

68. Lesage F, Terrenoire C, Romey G and Lazdunski M. (2000) Human TREK2, a 2P domain mechano-sensitive $\mathrm{K}+$ channel with multiple regulations by polyunsaturated fatty acids, lysophospholipids, and Gs, Gi, and Gq protein-coupled receptors. J Biol Chem 275: 28398-405 [PMID:10880510]

69. Levitz J, Royal P, Comoglio Y, Wdziekonski B, Schaub S, Clemens DM, Isacoff EY and Sandoz G. (2016) Heterodimerization within the TREK channel subfamily produces a diverse family of highly regulated potassium channels. Proc Natl Acad Sci USA 113: 4194-9 [PMID:27035963]

70. Lopes CM, Gallagher PG, Buck ME, Butler MH and Goldstein SA. (2000) Proton block and voltage gating are potassium-dependent in the cardiac leak channel Kcnk3. J Biol Chem 275: 16969-78 [PMID:10748056]

71. Lopes CM, Zilberberg N and Goldstein SA. (2001) Block of Kcnk3 by protons. Evidence that 2-Pdomain potassium channel subunits function as homodimers. J Biol Chem 276: 24449-52 [PMID:11358956]

72. Loucif AJC, Saintot PP, Liu J, Antonio BM, Zellmer SG, Yoger K, Veale EL, Wilbrey A, Omoto K and Cao L et al.. (2018) GI-530159, a novel, selective, mechanosensitive two-pore-domain potassium $\left(\mathrm{K}_{2 \mathrm{P}}\right)$ channel opener, reduces rat dorsal root ganglion neuron excitability. $\mathrm{Br} \mathrm{J}$ Pharmacol 175: 2272-2283 [PMID:29150838]

73. Maingret F, Fosset M, Lesage F, Lazdunski M and Honoré E. (1999) TRAAK is a mammalian neuronal mechano-gated K+ channel. J Biol Chem 274: 1381-7 [PMID:9880510]

74. Maingret F, Lauritzen I, Patel AJ, Heurteaux C, Reyes R, Lesage F, Lazdunski M and Honoré E. (2000) TREK-1 is a heat-activated background $\mathrm{K}(+)$ channel. EMBO J 19: 2483-91 [PMID:10835347]

75. Maingret F, Patel AJ, Lazdunski M and Honoré E. (2001) The endocannabinoid anandamide is a direct and selective blocker of the background $\mathrm{K}(+)$ channel TASK-1. EMBO J 20: 47-54 [PMID:11226154]

76. Maingret F, Patel AJ, Lesage F, Lazdunski M and Honoré E. (1999) Mechano- or acid stimulation, two interactive modes of activation of the TREK-1 potassium channel. J Biol Chem 274: 26691-6 [PMID:10480871]

77. Maingret F, Patel AJ, Lesage F, Lazdunski M and Honoré E. (2000) Lysophospholipids open the two-pore domain mechano-gated K(+) channels TREK-1 and TRAAK. J Biol Chem 275: 10128-33 [PMID:10744694]

78. Manjunath NA, Bray-Ward P, Goldstein SA and Gallagher PG. (1999) Assignment of the 2P domain, acid-sensitive potassium channel OAT1 gene KCNK3 to human chromosome bands 
2p24.1-->p23.3 and murine 5B by in situ hybridization. Cytogenet Cell Genet 86: 242-3 [PMID:10575216]

79. Mazella J, Pétrault O, Lucas G, Deval E, Béraud-Dufour S, Gandin C, El-Yacoubi M, Widmann C, Guyon A and Chevet E et al.. (2010) Spadin, a sortilin-derived peptide, targeting rodent TREK-1 channels: a new concept in the antidepressant drug design. PLoS Biol 8: e1000355 [PMID:20405001]

80. Meadows HJ, Benham CD, Cairns W, Gloger I, Jennings C, Medhurst AD, Murdock P and Chapman CG. (2000) Cloning, localisation and functional expression of the human orthologue of the TREK-1 potassium channel. Pflugers Arch 439: 714-22 [PMID:10784345]

81. Millar JA, Barratt L, Southan AP, Page KM, Fyffe RE, Robertson B and Mathie A. (2000) A functional role for the two-pore domain potassium channel TASK-1 in cerebellar granule neurons. Proc Natl Acad Sci USA 97: 3614-8 [PMID:10725353]

82. Morton MJ, Chipperfield S, Abohamed A, Sivaprasadarao A and Hunter M. (2005) Na(+)-induced inward rectification in the two-pore domain $\mathrm{K}(+)$ channel, TASK-2. Am J Physiol Renal Physiol 288: F162-9 [PMID:15328068]

83. Niemeyer MI, Cid LP, Barros LF and Sepúlveda FV. (2001) Modulation of the two-pore domain acid-sensitive K+ channel TASK-2 (KCNK5) by changes in cell volume. J Biol Chem 276: 4316674 [PMID:11560934]

84. O'Kelly I, Butler MH, Zilberberg N and Goldstein SA. (2002) Forward transport. 14-3-3 binding overcomes retention in endoplasmic reticulum by dibasic signals. Cell 111: 577-88 [PMID:12437930]

85. O'Kelly I and Goldstein SA. (2008) Forward Transport of K2p3.1: mediation by 14-3-3 and COPI, modulation by p11. Traffic 9: 72-8 [PMID:17908283]

86. Orias M, Velázquez H, Tung F, Lee G and Desir GV. (1997) Cloning and localization of a doublepore K channel, KCNK1: exclusive expression in distal nephron segments. Am J Physiol 273: F663-6 [PMID:9362344]

87. Ozaita A and Vega-Saenz de Miera E. (2002) Cloning of two transcripts, HKT4.1a and HKT4.1b, from the human two-pore $\mathrm{K}+$ channel gene KCNK4. Chromosomal localization, tissue distribution and functional expression. Brain Res Mol Brain Res 102: 18-27 [PMID:12191490]

88. Patel AJ, Honoré E, Lesage F, Fink M, Romey G and Lazdunski M. (1999) Inhalational anesthetics activate two-pore-domain background K+ channels. Nat Neurosci 2: 422-6 [PMID:10321245]

89. Patel AJ, Honoré E, Maingret F, Lesage F, Fink M, Duprat F and Lazdunski M. (1998) A mammalian two pore domain mechano-gated S-like K+ channel. EMBO J 17: 4283-90 [PMID:9687497]

90. Patel AJ, Maingret F, Magnone V, Fosset M, Lazdunski M and Honoré E. (2000) TWIK-2, an inactivating 2P domain K+ channel. J Biol Chem 275: 28722-30 [PMID:10887187]

91. Pei L, Wiser O, Slavin A, Mu D, Powers S, Jan LY and Hoey T. (2003) Oncogenic potential of TASK3 (Kcnk9) depends on K+ channel function. Proc Natl Acad Sci USA 100: 7803-7 [PMID:12782791]

92. Plant LD, Dementieva IS, Kollewe A, Olikara S, Marks JD and Goldstein SA. (2010) One SUMO is sufficient to silence the dimeric potassium channel K2P1. Proc Natl Acad Sci USA 107: 10743-8 [PMID:20498050]

93. Plant LD, Zuniga L, Araki D, Marks JD and Goldstein SA. (2012) SUMOylation silences heterodimeric TASK potassium channels containing K2P1 subunits in cerebellar granule neurons. Sci Signal 5: ra84 [PMID:23169818]

94. Pope L, Arrigoni C, Lou H, Bryant C, Gallardo-Godoy A, Renslo AR and Minor Jr DL. (2018) Protein and Chemical Determinants of BL-1249 Action and Selectivity for $\mathrm{K}_{2 \mathrm{P}}$ Channels. ACS Chem Neurosci 9: 3153-3165 [PMID:30089357]

95. Pountney DJ, Gulkarov I, Vega-Saenz de Miera E, Holmes D, Saganich M, Rudy B, Artman M and Coetzee WA. (1999) Identification and cloning of TWIK-originated similarity sequence (TOSS): a novel human 2-pore K+ channel principal subunit. FEBS Lett 450: 191-6 [PMID:10359073]

96. Rajan S, Plant LD, Rabin ML, Butler MH and Goldstein SA. (2005) Sumoylation silences the plasma membrane leak K+ channel K2P1. Cell 121: 37-47 [PMID:15820677]

97. Rajan S, Wischmeyer E, Karschin C, Preisig-Müller R, Grzeschik KH, Daut J, Karschin A and Derst C. (2001) THIK-1 and THIK-2, a novel subfamily of tandem pore domain K+ channels. $J$ Biol Chem 276: 7302-11 [PMID:11060316]

98. Rajan S, Wischmeyer E, Xin Liu G, Preisig-Müller R, Daut J, Karschin A and Derst C. (2000) TASK-3, a novel tandem pore domain acid-sensitive $\mathrm{K}+$ channel. An extracellular histiding as $\mathrm{pH}$ sensor. J Biol Chem 275: 16650-7 [PMID:10747866]

99. Renigunta V, Fischer T, Zuzarte M, Kling S, Zou X, Siebert K, Limberg MM, Rinné S, Decher N and Schlichthörl G et al.. (2014) Cooperative endocytosis of the endosomal SNARE protein syntaxin-8 and the potassium channel TASK-1. Mol Biol Cell 25: 1877-91 [PMID:24743596]

100. Renigunta V, Zou X, Kling S, Schlichthörl G and Daut J. (2014) Breaking the silence: functional expression of the two-pore-domain potassium channel THIK-2. Pflugers Arch 466: 1735-45 
[PMID:24297522]

101. Reyes R, Duprat F, Lesage F, Fink M, Salinas M, Farman N and Lazdunski M. (1998) Cloning and expression of a novel $\mathrm{pH}$-sensitive two pore domain $\mathrm{K}+$ channel from human kidney.J Biol Chem 273: 30863-9 [PMID:9812978]

102. Reyes R, Lauritzen I, Lesage F, Ettaiche M, Fosset M and Lazdunski M. (2000) Immunolocalization of the arachidonic acid and mechanosensitive baseline traak potassium channel in the nervous system. Neuroscience 95: 893-901 [PMID:10670456]

103. Salinas M, Reyes R, Lesage F, Fosset M, Heurteaux C, Romey G and Lazdunski M. (1999) Cloning of a new mouse two-P domain channel subunit and a human homologue with a unique pore structure. J Biol Chem 274: 11751-60 [PMID:10206991]

104. Sandoz G, Tardy MP, Thümmler S, Feliciangeli S, Lazdunski M and Lesage F. (2008) Mtap2 is a constituent of the protein network that regulates twik-related $\mathrm{K}+$ channel expression and trafficking. J Neurosci 28: 8545-52 [PMID:18716213]

105. Sandoz G, Thümmler S, Duprat F, Feliciangeli S, Vinh J, Escoubas P, Guy N, Lazdunski M and Lesage F. (2006) AKAP150, a switch to convert mechano-, pH- and arachidonic acid-sensitive TREK K(+) channels into open leak channels. EMBO J 25: 5864-72 [PMID:17110924]

106. Sano Y, Inamura K, Miyake A, Mochizuki S, Kitada C, Yokoi H, Nozawa K, Okada H, Matsushime $\mathrm{H}$ and Furuichi K. (2003) A novel two-pore domain K+ channel, TRESK, is localized in the spinal cord. J Biol Chem 278: 27406-12 [PMID:12754259]

107. Talley EM and Bayliss DA. (2002) Modulation of TASK-1 (Kcnk3) and TASK-3 (Kcnk9) potassium channels: volatile anesthetics and neurotransmitters share a molecular site of action. J Biol Chem 277: 17733-42 [PMID:11886861]

108. Talley EM, Lei Q, Sirois JE and Bayliss DA. (2000) TASK-1, a two-pore domain K+ channel, is modulated by multiple neurotransmitters in motoneurons. Neuron 25: 399-410 [PMID:10719894]

109. Terrenoire C, Lauritzen I, Lesage F, Romey G and Lazdunski M. (2001) A TREK-1-like potassium channel in atrial cells inhibited by beta-adrenergic stimulation and activated by volatile anesthetics. Circ Res 89: 336-42 [PMID:11509450]

110. Theilig F, Goranova I, Hirsch JR, Wieske M, Unsal S, Bachmann S, Veh RW and Derst C. (2008) Cellular localization of THIK-1 (K(2P)13.1) and THIK-2 (K(2P)12.1) K channels in the mammalian kidney. Cell Physiol Biochem 21: 63-74 [PMID:18209473]

111. Thomas D, Plant LD, Wilkens CM, McCrossan ZA and Goldstein SA. (2008) Alternative translation initiation in rat brain yields K2P2.1 potassium channels permeable to sodium. Neuron 58: 859-70 [PMID:18579077]

112. Toncheva D, Mihailova-Hristova M, Vazharova R, Staneva R, Karachanak S, Dimitrov P, Simeonov V, Ivanov S, Balabanski L and Serbezov D et al.. (2014) NGS nominated CELA1, HSPG2, and KCNK5 as candidate genes for predisposition to Balkan endemic nephropathy. Biomed Res Int 2014: 920723 [PMID:24949484]

113. Warth R, Barrière H, Meneton P, Bloch M, Thomas J, Tauc M, Heitzmann D, Romeo E, Verrey F and Mengual R et al.. (2004) Proximal renal tubular acidosis in TASK2 K+ channel-deficient mice reveals a mechanism for stabilizing bicarbonate transport. Proc Natl Acad Sci USA 101: 8215-20 [PMID:15141089]

114. Washburn CP, Sirois JE, Talley EM, Guyenet PG and Bayliss DA. (2002) Serotonergic raphe neurons express TASK channel transcripts and a TASK-like $\mathrm{pH}$ - and halothane-sensitive K+ conductance. J Neurosci 22: 1256-65 [PMID:11850453]

115. Wiedmann F, Kiper AK, Bedoya M, Ratte A, Rinné S, Kraft M, Waibel M, Anad P, Wenzel W and González W et al.. (2019) Identification of the A293 (AVE1231) Binding Site in the Cardiac TwoPore-Domain Potassium Channel TASK-1: a Common Low Affinity Antiarrhythmic Drug Binding Site. Cell Physiol Biochem 52: 1223-1235 [PMID:31001961]

116. Woo DH, Han KS, Shim JW, Yoon BE, Kim E, Bae JY, Oh SJ, Hwang EM, Marmorstein AD and Bae YC et al.. (2012) TREK-1 and Best1 channels mediate fast and slow glutamate release in astrocytes upon GPCR activation. Cell 151: 25-40 [PMID:23021213] 